УДК $2+305$

DOI: $10.21847 / 1728-9343.2018 .3(155) .139316$

\title{
СТАРОВОЙТ ІРИНА,
}

аспірантка кафедри релігієзнавства,

Київський національний університет ім. Т. Шевченка

\section{ПРОБЛЕМА ГЕНДЕРУ ТА ЖІНОЧОї ОРДИНАЦІї: ВАРІАТИВНІСТЬ ТЛУМАЧЕНЬ У РІЗНИХ КОНЦЕПЦІЯХ ФЕМІНІСТСЬКОї ТЕОЛОГІї}

\begin{abstract}
У статті автор досліджує питання становлення феміністської теології, розглядає ідеї видатних представниць феміністичної теології щодо проблеми гендеру в релігії, а також аналізує ключові риси протестантизму як базису для становлення жіночої ординації.
\end{abstract}

Ключові слова: гендер; ординація; протестантизм; теологія; фремінізм.

Постановка і стан дослідження проблеми. Феміністська теологія зокрема і проблема гендеру загалом, мають дуже багато спільних конотацій. У науковій літературі феномен жіночого вже знайшов визнання як культурне, так і соціальне. Ця тематика є предметом постійних розвідок у різних галузях - від фрілософрії, психології, соціології, антропології до релігієзнавства. Упродовж становлення сучасної цивілізації жінками вже створено власний духовний простір, який $є$ цілісним, самостійним, автентичним і відмінним від чоловічого. У зв'язку із цим наразі все частіше порушується проблема гендеру в релігії, особливо актуальним постає їі розгляд у феміністській теології. Наслідком такого розвитку мислення та парадигми $€$ формування та легалізація жіночої ординації різними деномінаціями протестантизму.

Предтечею формулювання гендерної проблематики в протестантизмі став феміністичний рух, який особливо потужно розвивався в Англії, починаючи з XV ст. Однак найбільш радикального та бурхливого розвитку він набуває у другій половині $X X$ ст. 360 -х років $X X$ ст. феміністські теоретики почали викриття сексизму в християнстві. Саме цим часом датують становлення окремого напряму теології - феміністичного [Lerner, 1975]. Опрацьовуючи літературу, можемо знайти факти, що феміністичний рух у християнстві бере початок від групи американських християнок на чолі з Елізабет Стентон. Учасниці групи на своїх зібраннях вивчали Святе Письмо на предмет опису та згадування в ньому жінок. Наслідком цих зустрічей стала так звана "Woman's Bible" ("Жіноча Біблія"), видана у двох частинах 1895 р. та 1898 р. Книга мала відмінне від традиційного трактування, тому релігійними колами була сприйнята досить неоднозначно. Однак сам фракт ії виходу у світ став суттєвою ознакою формування нової свідомості жінки не лише у громадянському суспільстві, а й усередині самої церкви. Ця подія заклала фрундамент для подальшого розвитку проекту "жіночої теології" [Айвазова, 1991: 23].

3 точки зору американського фемінізму, публічна теологія виступає однією з форм "товару" або "послуги", де ступінь їі "доступності", для всіх громадян (включно 3 жінками) є одним із показників демократичності культури. 3 цієї позиції жоден текст не може розглядатися як такий, що має остаточне й завершене знання, тому що демократія передбачає безперервне виробництво нових практик, цінностей та інтерпретацій, що з найбільшою повнотою забезпечують можливості самовтілення та ідентифрікації індивідів. Деконструкція релігії розкриває цінності світу, розділеного на бінарні категорії жіноче/чоловіче, і ставить під сумнів гендерні відносини як "описові" [Burns S. \& Monro A., 2015]. Таке бачення дає поштовх поліваріантності тлумачень, новим поглядам і теологічним течіям. У зв'язку із цим феміністська теологія робить предметом свого дослідження священні тексти й догмати релігії, дозволяючи собі бачити в релігії нарацію, доступну феміністській критиці, яка $є$ відкритою для реінтерпретації. Для реалізації цієї мети теоретики фемінізму звернулися до методології дослідження постмодернізму та екзистенціалізму [Lovibond S., 1990; Mahon J. and Campling J., 1997]. Не варто стверджувати, що феміністки, які працюють в аспекті феміністичної теології, ставляться вороже до релігії або ж навпаки - є тільки віруючими особистостями. Ідеї феміністської теології є досить неоднорідними. Звичайно ж, у цілому спрямованість феміністської думки єдина - подолання статевої дискримінації в духовній сфрері, але існує різниця в тому, наскільки далеко готові піти дослідниці в цьому напрямку. Існує величезне поле можливостей, починаючи від боязкої ліберальної критики релігійних традицій, закінчуючи проектами створення альтернативної жіночої релігійності.

Дослідниця гендерної проблематики в релігії В. Суковата, аналізуючи появу феміністських та гендерних досліджень у теології, відзначає, що в результаті розвитку жіночої самосвідомості найактивніші жінки, "посилаючись на приклади з Біблії, виступали проти подвійного стандарту релігійної моралі, вимагали внесення гендерного егалітаризму в релігію і теологію та визнання заслуг жінок у розвитку духовності, а також перегляду ряду дискримінаційних практик, які проявлялись у забороні вивчення жінками священних текстів, викладання теології та ведення служби" [Суковата, 2004: 423].

Перш ніж розглядати докладніше звернення до проблеми гендеру у феміністській теології варто зазначити найбільш відомих її представників, як-от: С. Бовуap, М. Дейлі, К. Келлер, А. Мілано, Л. Ірігарей тощо.

Мета дослідження - визначити зв'язок між ключовими концепціями феміністської теології, подіями все- 
редині протестантських деномінацій та появою жіночої ординації з кінця XX століття.

Виклад основного матеріалу. Феміністська теологія від початку свого існування розроблялася представниками різних конфесій і виступала проти "андроцентризму" (культурна ідея, у рамках якої чоловіка сприймають як норму людськості) у розумінні людини, тобто вимагала звільнити християнську антропологію від сексизму. Із цього приводу А. Мілано у своїй праці "Жінка та любов у Біблії. Ерос, агапа та особистість" указує: "Феміністки міцно пов'язали андроцентризм з антропологічним дуалізмом, характерним для західної культури, розуміючи під ним протилежність душі та тіла, що з часів античності вкорінилася в соціально-політичній та культурній структурах патріархального устрою. Якщо андроцентризм став панівним умонастроєм, то патріархат перетворився на систему, де чоловіки здійснюють свою владу, перш за все, над жінками, але також і над дітьми, над рабами, над цілими народами. Згідно із цим "ядром" фреміністської інтерпретації, принижене положення жінок випливає не із вроджених біологічних відмінностей між статями, а з патріархальної системи та її законів у сфрері власності, сім'ї, подружніх відносин: "статеві відмінності" між чоловіком та жінкою тим самим не задані природою, а скоріше являються по своїй суті соціальною конструкцією, творенням "культури" в їі різноманітних формах і проявах" [Милано A., 2011: 15].

Інша представниця феміністської теології К. Келлер, розглядаючи усталену статеву приналежність Бога, зауважує: "Те, якими словами ми називаємо Бога, має величезне значення для нашого власного самовизначення, для формування нашого ідеалу, тому неприпустимо використовувати стару містичну мову. Проблема полягає не в самому Богові, а в тому, що деяка група людей затвердила монополію на божественне зображення" [Келлер Х., 2003: 145].

Однією із найвідоміших прихильниць феміністської теології є С. Бовуар. У своїх працях"Друга стать" і "Містика" вона звертає увагу на жіночу релігійність, особливо на містичний жіночий досвід у межах християнської традиції [Бовуар С., 1994]. Щодо гендерної проблеми в релігії С. Бовуар пише: "В епоху, коли людство досягло такого рівня розвитку, що змогло записати свою міфологію і закони, патріархат уже остаточно був установлений - звід законів сформували чоловіки. Цілком природно, що жінці вони відвели підлегле становище, але можна було б очікувати, що вони поставляться до неї настільки ж доброзичливо, як до дітей або до домашніх тварин. Нічого подібного. Закріплюючи панування над жінкою, законодавці самі ії бояться. У її амбівалентних властивостях виділяють лише згубний аспект: зі священної вона стає нечистою. Єва, дарована Адаму, щоб стати його подругою, погубила людський рід" [Бовуар С., 1994: 15]. Можна зазначити, що дослідниця розглядає жіночу релігійність у термінах, які мають відношення до чоловічої ідентифрікації, і стверджує, що жінки змушені були прийняти розуміння їх суб'єктивності через чоловіче трактування. Вона вважає, що релігія, замість того, щоб вирішити цю проблему, навпаки, її підтримує та максимізує. Любов у релігії є вищим призначенням жінки, її покликанням, і коли вона наближається до чоловіка, то шукає в ньому Бога, але якщо жінка розчаровується в такій любові, то вона може вибрати предметом обожнювання - божественне, самого Бога. Таким чином, жінки переносять свої франтазії щодо чоловіків на Бога. Жінок уважають нездатними досягти трансцендентного чоловічого Бога ніякими іншими способами, крім як через чоловіків. Жінки бачать у чоловіках і в чоловічому Бога, джерело всіх цінностей і значень [Бовуар С., 1994: 134]. У такий спосіб С. Бовуар підкреслює залежність позиції жінки, яку дуже довго впроваджували, нав'язували і до якої закликали або схиляли як соціальні, політичні та культурні інститути, так і релігійні догмати.

Однією з найбільш яскравих фрігур феміністської теології $€$ М. Дейлі. ІІї вважають засновницею радикальної феміністської теології. У найбільш ранній своїй роботі "Церква і друга стать" (1975) М. Дейлі звернула увагу на патріархальне упередження проти жінок і зазначила, що таке упередження суперечить християнському Євангелію [Daly M., 1978: 87]. Вона рекомендувала методи, якими можна скористатися з метою відновлення рівності для жінок. Так, вона запропонувала змінити саме поняття Бога. Вона зазначила, що визначені ідентифрікації Бога з чоловічою статтю проникли в християнське богослов'я, незважаючи на парадокс, суть якого полягає в тому, що християнський Бог намагається бути вищим від статевого розподілу. Вона задається питанням, чому Бог асоціюється з чоловічим, якщо в Бога немає статі. Окрім того, М. Дейлі піддала феміністській критиці латентне чоловіче авторство християнства. Вона спробувала розглянути Бога через поняття становлення, використовуючи для його позначення дієслово. У своїх концепції М. Дейлі дематеріалізує Бога, визначає його як динамічну енергію [Daly M., 1978: 156]. Варто зауважити, що вона не започатковує аналіз та дослідження цього питання, а спирається на ідеї американського богослова Дж. Б. Кобба-молодшого, який розглядав Бога як динамічне становлення, і на ідеї німецько-американсько-протестантського теолога і філософра-екзистенціаліста П. Тілліха, для якого Бог був підставою буття і джерелом сміливості перед обличчям екзистенціальної свободи. Ґрунтуючись на ідеях Джона Б. Кобба і П. Тілліха, М. Дейлі доходить висновку, що нове поняття Бога дає можливість нової конфігурації суспільства. Бога:

Таким чином, у концепції М. Дейлі існує три поняття

- міфрічне,

- лінгвістичне,

- метафізичне.

Міфічне розуміння пов'язане з розповіддю про спокуту, викладається відповідно до християнських понять, але розглядається в канві фемінізму.

Суть лінгвістичного поняття в тому, що Божество не просто називають дієсловом, а швидше за все дієслова й усі інші слова мають онтологічний статус, поза людським використанням. Тут ми спостерігаємо момент схожості з платонівським ученням і з середньовічним реалізмом. Слова, які мають онтологічне значення, існують у жіночій свідомості, наприклад, слова амазонка, стара діва, мегера, янгол.

Метафрізичне визначення Бога, що розглядається в такому контексті, будується не як метафрізика сутності, а як метафрізика процесу [Daly M., 1978: 158].

Звичайно ж, ці її ідеї не були схвалені церквою, але, тим не менш, сприяли розвитку феміністської теології і стали базисом для нівеляції приниження жіноцтва в релігійній сфері. Однак тут простежувалася інша крайність: у своїх найбільш радикальних поглядах М. Дейлі проголошувала вроджену й беззаперечну перевагу жінок над чоловіками та необхідність побудови сус- 
пільства майбутнього та релігії на домінації жіночності й непотрібності чоловіків: ціль життя жінки - щастя і свобода, а не сім'я і діти, тому нова раса жінок буде розмножуватися завдяки досягненням науки. Такий радикальний фемінізм бореться вже не за рівність статей, а за перевагу "вищої раси" - жіночої, що є переглядом традиційних основ людської цивілізації і відходом від концепції гендерного рівноправ'я.

Після аналізу підходів та концепцій представниць феміністської теології стає очевидним їх прагнення уявити можливість існування жіночого досвіду духовності, що могло б зміцнити позиції жінок і в психологічному, і в політичному плані, створити противагу чоловічій культурі.

Розглянувши ключові тези із праць представниць феміністської теології, можемо висновувати, що однією з дуже важливих була тема жіночого священства. Однак не всі християнські напрямки підтримували чи бодай просто не заперечували проти такого вектора розвитку свідомості для жіночої половини людства. Першим і найбільш лояльним напрямком став протестантизм. Протестантське розуміння пастирського служіння помітно відрізняється від православного та католицького. Станом на сьогодні в більшості протестантських деномінацій уже давно залишилися позаду бурхливі дебати на цю тему, у багатьох церквах і громадах жінки допускаються до богослужіння.

Протестантизм від самого початку свого розвитку був орієнтований на інше ставлення до звичних та традиційних для християнства стереотипів. Батьки Реформації М. Лютер, Ж. Кальвін уже в XVI столітті однозначно відкинули погляд на священство як на таїнство. Та й сам термін "священик" по відношенню до служителя церкви більшість протестантів уважають неприйнятним. Протестанти ставлять порятунок душі в залежність від внутрішньої віри й особистих справ, відмовляючись від будь-яких посередників між віруючими та Богом. Людина здатна безпосередньо спілкуватися з Богом. Звідси й виникає можливість священства всіх віруючих.

Незважаючи на те, що деякі з протестантських конфесій зберегли традиційну систему пастирського служіння, вони вважають їі лише даниною історичній традиції. У зазначеному контексті важливо згадати визначний історичний факт: першою ординованою жінкою, посвяченою в сан, стала Антуанетта Браун в Конгрегаційній церкві США в 1853 році [Суковата В., 2004: 65].

Проте переважна більшість деномінацій протестантизму не розглядали питання жіночої ординації серйозно аж до другої половини XX століття, що співпадає з піком феміністської боротьби із сексизмом. Саме із цього часу жіноча ординація стає дозволеною в низці протестантських церков Європи з численними вірянами. 3 80-х років XX ст. жінок починають висвячувати в сан єпископів, зокрема в методистській, пресвітеріанській, лютеранській та низці інших церков [Петрушкевич М., 2012: 27].

Розглядаючи це питання, сучасний дослідник В. Бурега висловлює думку, що "сьогодні словосполучення "жіноче священство" стало вже певним штампом, міцно пов'язаним із західним християнством. Саме "жіноче священство" вважається одним з основних індикаторів секуляризаційних процесів, що охопили сучасний протестантизм" [Бурега В., 2012].

Священство для протестантів - це не сан, а посада. Тому вони вважають, що перешкодою до висвячування жінок в давнину була лише соціально-культурна тради- ція тих часів і на сьогодні потрібно лише відновити справедливість та зрівняти в правах жінок і чоловіків. Можна стверджувати, що у протестантизмі вперше було впроваджено фемінізацію доцерковного життя (на прикладі англіканства). I це відбулося з декількох причин: по-перше, це активне залучення у внутрішньоцерковне життя чоловіків-мирян; по-друге, це зміна пріоритетів і сорери відповідальності в житті священнослужителя, що було пов'язано зі змінами в суспільному житті; по-третє, це реформування жіночої освіти і, як наслідок, залучення жінок до соціального служіння в церковних структурах; по-четверте - формування "класу" незалежних жінок, які почали утворювати жіночі організації та співтовариства.

Гендерні ролі відображають соціальний контекст протестантських церков. Як відомо, протестантські деномінації можуть бути як ліберальних, так і консервативних поглядів. У Європі протестантські церкви спрямовані до гендерної рівноправності й уважаються досить ліберальними. У ліберальних відгалуженнях протестантського християнства жінки можуть бути у складі духовенства. В інших напрямках за жінками визнається право стати "священиками" і співати в хорі [Andermahr S., Lovell T. and Wolkowitz C., 2000: 99].

Для сучасної епохи характерною ознакою постає злам старих стереотипів мислення, ідеологічних схем та становлення нових духовних засад суспільного розвитку. Дихотомія "жінка і релігія" набуває особливої актуальності. Оскільки для протестантизму від самого початку існування властиве постійне оновлення, переосмислення ідей та смислів, то цілком логічним постає різне ставлення протестантських течій до питань гендерної проблематики. Конкретизуючи таку тенденцію, варто згадати промовисті факти на прикладі англіканської церкви.

Починаючи з 1994 року, в англіканській церкві жінкам було дозволено служити священиками, і це рішення призвело до того, що велика кількість чоловіківсвящеників на знак протесту покинули англіканську церкву і перейшли до римо-католицької. Питання про жінок-єпископів викликає поділ серед англіканських священнослужителів ще відтоді, як Синод уперше схвалив висвячування жінок-священиків. Реформатори, які з метою боротьби зі зменшенням кількості прихожан англіканської церкви, виступали за більш сучасний образ церкви, протистояли консервативній меншості, представники якої запевняли, що подібні зміни суперечать Біблії. Незважаючи на те, що в більшості протестантських церков сьогодні повністю схвалена ординація жінок, практично в усіх цих церквах існують консервативні групи, що відкидають допуск жінок до пасторського служіння.

\section{Висновки}

Отже, на думку багатьох сучасних авторів, які досліджують феномен фемінізму, питання жіночого священства виникає як синтез фемінізму і своєрідного витлумачення богословського вчення про священство в протестантизмі. Слід зазначити, що актуалізація питання про висвячування жінок у священний сан зумовлена відсутністю прямих заборон у Священному Писанні.

3 появою феміністичних рухів робляться спроби подолання існуючої патріархальної традиції в християнстві, яка негативно ставиться до жіночого священства. Завдяки зусиллям активісток релігійних жіночих рухів така деномінація протестантизму як англікансь- 
ка церква першою переглянула свої правила й допустила жінок до лав ієрархів.

Принцип загального священства розуміється буквально й поширюється на всіх без винятку віруючих, у тому числі й на жінок, без будь-яких обмежень і застережень у ряді релігійних протестантських організацій: церкви євангельських християн п'ятидесятників сіоністів (ЕХПС), єпископальної пресвітеріанської лютеранської церкви США, національної асоціації Конгрегаціоналістської християнських церков, Англіканської церкви, Шотландської єпископальної церкви, ФЛЦ, Євангельсько-реформаторської церкви Польщі, церкви євангельських християн святих сіоністів (ЕХCC). У цих релігійних об'єднаннях жінки відіграють велику роль у релігійному житті. У 1994 р. церква Англії остаточно затвердила на канонічному рівні жіноче право на священство, і в цьому ж році були висвячені перші жінки священики.

Підсумовуючи, варто зазначити, що перемога фреміністського руху у світській сфрері впливала на жваву реакцію активісток і в релігійних напрямках. Феміністські теоретики почали викриття сексизму в християнстві з 60-х років XX ст. У цей самий час відбулося становлення окремого напряму теології - феміністичного. До видатних представників належать С. Бовуар, М. Дейлі, Л. Ірігарей та ін. Їхні праці заклали фундамент розуміння необхідності рівності гендерних відносин у релігійній copepi.

Принцип гендерної рівності, на якому наполягали численні жіночі рухи, довгий період часу не отримував схвалення з боку богослов'я та інституту церкви ні в родині, ні, тим більше, у громадській сфері. Доступ до суспільного життя для жінок у межах теологічних підходів був досить обмежений, участь жінки можлива була лише в тих сферах, де вона може виконувати все те ж "жіноче призначення": виховувати, піклуватися про хворих, утішати та підтримувати. Поява феміністичних рухів та феміністської теології цю ситуацію зуміла спрямувати в новий вектор руху та розвитку. І хоча стосовно дійсної фактуальної соціальної рівності церква здебільшого все ще займає негативну позицію, завдяки феміністській теології стала можливою зміна такої парадигми й відбувся поштовх до започаткування френомену жіночої ординації. Протестантизм із трьох гілок християнської традиції є найбільш лояльним у питанні ординації жінок. Це пов'язано з тим, що низці протестантських церков притаманна егалітарна тенденція (позиція рівності).

\section{ЛIТРАТУРA}

1. Lerner Gerda. Placing Women in History: Definitions and Challenges. Feminist Studies 3, 1975. № 1/2: 5-14. DOI: 10.2307/ 3518951.

2. Айвазова С. Истоки феминизма. Искусство кино. 1991. № 6. C. 21-24.

3. Burns, S. (ed.), Monro, A. (ed.). Public Theology and the Challenge of Feminism. London: Routledge, 2015. DOI: 10.4324/ 9781315744223.

4. Lovibond S. Feminism and Postmodernism. In: Boyne R., Rattansi A. (eds) Postmodernism and Society. Communications and Culture. Palgrave, London, 1990. DOI: 10.1007/978-1-34920843-2_6

5. Mahon J., Campling J. Existentialism and the Origins of Male Supremacy. In: Campling J. (eds) Existentialism, Feminism and Simone de Beauvoir. Palgrave Macmillan, London, 1997. DOI: 10.1057/9780230376663 12

6. Суковата В. Гендер і релігія. Основи теорії гендеру. Київ: К.І.С, 2004. С. 383-425.

7. Милано А. Женщина и любовь в Библии. Эрос, агапа, личность / пер. с итал. А. Бакулова, М. Талалая. СПб.: Алетейя, 2011. С. 14-15.

8. Келлер Х. История моей жизни = Story of My Life and Other Texts. СПб: Захаров, 2003. С. 145.

9. Бовуар С. де. Друга стать. Перекл. з французької Н. Воробйової, П. Воробйова, Я. Собко. У 2 т. Том 1. Київ: Основи, 1994. $390 \mathrm{c}$

10. Daly Mary. Beyond God the Father. Toward a Philosophy of Women's Liberation, Beakon Press, Boston, 1978. 158 p.

11. Петрушкевич М. Ординація жінок як прояв релігійної ідентичності (соціокультурний огляд). Острозька Академія. 2012. № 9. C. $26-27$.

12. Бурега В. Проблема "женского священства" в современном протестантизме. URL: http://www.bogoslov.ru/text/ 2364041.html (дата звернення: 11.04.2018).

13. Andermahr Sonya [ed.], Lovell Terry [ed.] and Wolkowitz Carol [ed.] A Glossary of Feminist Theory. London: Arnold; NewYork: Oxford University Press, 2000. P. 99.

Starovoit Iryna,

postgraduate student, Department of Religious Studies, Taras Shevchenko National University, Kyiv

\section{THE PROBLEM OF GENDER AND WOMEN'S ORDINATION: VARIABILITY OF INTERPRETATION IN DIFFERENT CONCEPTS OF FEMINIST THEOLOGY}

The article offers an overview of the concepts of prominent representatives of feminist theology devoted to the gender problem in religion, and also analyzes the key features of Protestantism as a basis for the formation of women's ordination. The purpose of this article is to study the relation between the key principles of feminist theology, events within the Protestant denomination - Anglicanism and the emergence of women's ordination of the late of the twentieth century.

The author found that the emergence of feminist movements gave impetus to reassess the existing patriarchal traditions in Christianity, which assigns women only a minor role in the church and in the most radical reading reduces her essence to sin. The victory of the feminist movement in the secular sphere also had a significant influence in religious directions. Feminist theorists began exposing sexism in Christianity since the $1960 \mathrm{~s}$. At the same time there was the formation of separate direction of theology - feminist. Among the prominent representatives are S. Beauvoir, M. Daley, L. Irigarey, and others. Their works laid the new paradigm and the foundation for understanding the need for equality of gender relations in the religious sphere. Thanks to the efforts of activists of religious women's movements, such a denomination of Protestantism as the Anglican 
Church first revised its rules and allowed women to ranks of the hierarchy. Protestantism is the most loyal on the issue of the ordination of women from the three branches of the Christian tradition. This is due to the fact that a number of Protestant churches are characterized by the egalitarian tendency (position of equality).In 1994, the Church of England finally approved at the canonical level the women's right to the priesthood, and in the same year the first women were ordained priests. The conclusion comes by the issue of female priesthood arises as a synthesis of feminism and original interpretation of the theological doctrine of the priesthood in Protestantism: the priesthood for Protestants is not a san, but a post. In this connection, they consider that an obstacle to the ordination of women in ancient times was only a socio-cultural tradition of those times and today only need to restore justice and equal rights for women and men. In addition, the actualization of the question of the ordination of women in the holy ward is due to the absence of direct prohibitions in the Scriptures.

Key words: gender; ordination; Protestantism; theology; feminism.

\section{REFERENCES}

1. Lerner, Gerda. 1975. Placing Women in History: Definitions and Challenges. Feminist Studies 3, no. 1/2: 5-14. DOI: 10.2307/ 3518951.

2. Aivazova, S. 1991. Origins of feminism. Iskusstvo kino. № 6: 21-24 (rus).

3. Burns, S. (Ed.), Monro, A. (Ed.). 2015. Public Theology and the Challenge of Feminism. Routledge. London. DOI: 10.4324/ 9781315744223.

4. Lovibond, S. 1990. Feminism and Postmodernism. In: Boyne R., Rattansi A. (eds) Postmodernism and Society. Communications and Culture. Palgrave, London. DOI: 10.1007/978-1-349-20843-2_6

5. Mahon, J. and Campling, J. 1997. Existentialism and the Origins of Male Supremacy. In: Campling J. (eds) Existentialism, Feminism and Simone de Beauvoir. Palgrave Macmillan, London. DOI: 10.1057/9780230376663_12

6. Sukovata, V. 2004. Gender and religion. In: Fundamentals of the theory of gender. Kyiv: K.I.S: 383-425 (ukr).

7. Milano, A. 2011. Woman and love in the Bible. Eros, agape, personality [translat.]. Aleteya, St. Petersburg: 14-15 (rus).

8. Keller, H. 2003. Istoriya moyey zhizni = Story of My Life and Other Texts. Zakharov Publisher, St.Petersburgb: 145 pp. (rus).

9. Beauvoir, S. de \& Vorobyova, N. [translat.], Vorobyov, P. [translat.], Sobko, I. [translat.] 1994. The second sex. Volume 1. Osnovy, Kyiv, 390 p. (ukr).

10. Daly, Mary. 1978. Beyond God the Father. Toward a Philosophy of Women's Liberation, Beakon Press, Boston p.158.

11. Petrushkevych, M. 2012. Ordination of women as a manifestation of religious identity (sociocultural review). Ostroh Academy. № 9: 26-27.

12. Burega, V. 2012. The problem of «female priesthood» in modern Protestantism. Available at: http://www.bogoslov.ru/text/ 2364041.html (Accessed: 11.04.2018).

13. Andermahr, Sonya [ed.], Lovell, Terry [ed.] and Wolkowitz, Carol [ed.] 2000. A Glossary of Feminist Theory. London: Arnold; NewYork: Oxford University Press, P.99.

(C) Starovoit Iryna

Надійшла до редакції 24.04.2018 